\title{
Newcomers from the Periphery: The International Expansion of Polish Automotive Companies
}

\author{
Grzegorz Micek*D, Robert Guzik (D), Krzysztof Gwosdz and Bolesław Domański \\ Institute of Geography and Spatial Management, Jagiellonian University, 30-387 Kraków, Poland; \\ robert.guzik@uj.edu.pl (R.G.); krzysztof.gwosdz@uj.edu.pl (K.G.); boleslaw.domanski@uj.edu.pl (B.D.) \\ * Correspondence: grzegorz.micek@uj.edu.pl
}

Citation: Micek, G.; Guzik, R.; Gwosdz, K.; Domański, B.

Newcomers from the Periphery: The International Expansion of Polish Automotive Companies. Energies 2021, 14, 2617. https:// doi.org/10.3390/en14092617

Academic Editor: Victor Manuel Ferreira Moutinho

Received: 11 March 2021

Accepted: 28 April 2021

Published: 3 May 2021

Publisher's Note: MDPI stays neutral with regard to jurisdictional claims in published maps and institutional affiliations.

Copyright: (C) 2021 by the authors. Licensee MDPI, Basel, Switzerland. This article is an open access article distributed under the terms and conditions of the Creative Commons Attribution (CC BY) license (https:/ / creativecommons.org/licenses/by/ $4.0 /)$.

\begin{abstract}
The rapid growth of Central European economies has been related to inward FDI, so these countries are often regarded as dependent market economies. What is interesting in this context is the international expansion of some domestic-owned manufacturing companies from Central Europe. Looking through the lens of global production networks (GPN) and evolutionary resilience perspectives, the paper aims to identify paths and mechanisms of development of new multinational companies, namely Polish automotive firms expanding from around 2010 onwards in the global markets through acquisitions and greenfield investments in Western Europe, North America, and Asia. The authors ponder on the underlying motives and barriers of this process, the capabilities, and features of Polish-owned companies. In order to do it, both qualitative (13 interviews with representatives of new multinationals and the other stakeholders preceded by content analysis of various documents, including company annual reports in particular) and quantitative (analysis of international trade, revenues, employment, locational data) insights are used for the period covering the time span between 1999 and 2020. As the result, the international expansion of domesticowned firms is interpreted as a specific critical conjuncture of three mechanisms: (1) development of Central-Eastern European economies since the end of communism, (2) the evolution of the Western European core, and (3) the trajectory of individual Polish firms. We argue development trajectories of the firms going global cannot be understood without taking into account the dynamic interdependence between firm-specific capabilities (including the position within GPNs) and the changing characteristics of the countries (e.g., evolving regional assets).
\end{abstract}

Keywords: new multinational companies; automotive industry; Central Europe; industrial upgrading; global production networks; evolutionary resilience; adaptability; electromobility transition

\section{Introduction}

There is an ongoing discussion and growing interest on why some regional economies manage to prosper and develop well, while others remain unable to adapt to an increasingly globalizing world [1]. One of the theoretical frameworks that shed some light on the success and decline of regional economies is the regional adaptability and regional resilience perspective. Martin and Sunley [2] identified three distinct, but not necessarily exclusive, conceptualizations, further operationalized in research, of resilience: the first is the resilience as ability to return to the equilibrium after a shock or crisis; the second is the ability to absorb the shock without changes in structure and function of system or studied entity, and in the third, the resilience is understood as "positive adaptability" in anticipation of, or in response to, shocks. This third perspective, as it involves structural and operational adaptations in response to shocks, even those anticipated, is sometimes called "evolutionary resilience" [3]. This third perspective focuses more on adaptation as transformation process rather than as a system characteristics [4], therefore it is better suited for unpacking "the black box" of regional economic resilience by looking into actions of capable agents, such as companies, organizations, or governing bodies in evolutionary manner. Despite criticism [2,5] the evolutionary resilience perspective provides an interesting point of departure for analyzing cases 
of companies (business enterprises), which have used crisis and economic shocks and/or structural changes in their industries for their development and escape from path-dependent lock-in. It is especially interesting in case of the highly competitive automotive industry, heavily dominated by multinational companies controlling and organizing their supply and value chains from core regions and core economies.

The financial crisis of 2009, and subsequent problems of main automakers, caused huge perturbations in the automotive industry. It was heavily struck with further pressures and demands for its greening and the need of forthcoming electromobility revolution that has provided a window of opportunity for changes and potential industrial upgrading of companies and regions of integrated peripheries [6]. The dynamic expansion of the automotive industry into new integrated peripheries in the last decade, as described by Pavlínek [6], along with some positive factors, such as location in Poland of the largest EV battery plant by LG Chem and/or the success story of domestic Solaris company (the largest manufacturer of electric buses in Europe), have woken up high ambitions expressed by the Polish government and materialized in its official programme-Electromobility Development Plan adopted by the Polish Council of Ministers in 2017. This strategy has set plans for one million EVs on the road by 2025. Moreover, these cars were to be manufactured in Poland by domestic companies. Despite its unrealistic goals, even a partial success of this scenario is heavily dependent on what Mordue and Sweeney [7] have argued to be the main concern for the automotive industry in integrated peripheries (such as Poland, Czechia, or Mexico). These are ways to upgrade to more value-added activities. A first step to achieve this is to identify the companies which are capable of such upgrading and to understand mechanisms of such anticipatory adaptation. Hence, the paper identifies mechanisms of development of new Polish automotive multinationals, along with motives and barriers behind the growth of such enterprises.

The remaining part of the paper is divided into six sections. The next one introduces the research aim and scope, and consequently discusses research methods. Section 3 contains the literature review. It covers three topics: global production networks, the concepts explaining the growing role of new multinationals from peripheral areas, and the publications explaining the role of Central Europe (CE) in the automotive industry. Based on statistical data, Section 4 provides a brief overview of the contemporary development of the CE and Polish automotive sector. Four Polish automotive companies, which have gone global in the previous decade, are examined in some detail in Section 5. This is followed by a discussion of results, including a contribution to broader studies of GPN in the automotive sector and the changing role of new multinationals, the novelty of the paper, and the limitations of the study. The concluding remarks and directions of future research are presented in the final section.

\section{Aims, Scope of the Paper and Research Methods}

The paper aims to identify mechanisms of development of new multinationals in the case of Polish automotive firms expanding in the global markets, among other things through acquisitions and greenfield investments in Western Europe, North America, and Asia. Hence, the following research question is posed: "What are the mechanisms of development of the largest new Polish automotive multinationals?". The authors ponder on the underlying motives and barriers of this process, the capabilities and features of Polish-owned companies, as well as the impact on their position in global production networks. The four case studies include the three largest new Polish multinationals in the sector: Boryszew, Wielton, and Sanok Rubber, as well as Groclin as the first company which expanded abroad. They are analyzed using company reports and interviews. The other cases of the Polish automotive companies include enterprises with very limited foreign expansion (maximum two factories controlled abroad).

Three trajectories of establishing new multinational companies and the upgrading of these companies based in the periphery in global production networks may be distinguished: 
- upgrading of foreign-owned subsidiaries,

- promotion of state-led companies and/or conglomerates,

- expansion of private, domestic firms (analyzed in the paper).

There are at least five reasons behind conducting selected studies:

1. GPN concept is neglected in the studies of the automotive industry and, as a relational framework, fits well in the analysis of development of large automotive companies.

2. Outward FDI in the automotive industry from semi-peripheral countries are significant and tend to be a result of increased international competitiveness of indigenous companies [8].

3. There is an urgent need to combine a growing number of related approaches: GPN (including the "strategic coupling" construct, understood sometimes as firm-specific capabilities and country(regional)-specific advantages), literature covering the topics of localized capabilities, upgrading, and emergence of new multinational companies.

4. What has attracted much less attention is possible growth and international expansion of domestic-owned enterprises. This is a relatively new phenomenon, which has been largely ignored due to the domination of foreign TNCs in the CE automotive industry. At the same time, the international success of domestic producers may have a significant impact on the future development and position of the CE automotive sector in global production networks.

5. The case of Polish companies going global is particularly interesting considering Poland's inferior position in global production networks (integrated periphery) and the absence of an active industrial policy towards domestic companies during the long transformation period after 1989. The literature lacks an in-depth discussion of such a context of company internationalization. The existing contributions concentrate on explaining different types of internationalization undertaken by emerging countries with strong support for local OEM's, such as in the case of China or South Korea [9].

Thus, there is generally twofold motivation of this study: first, to explore a recent, largely under-researched phenomenon of the development of new multinationals from the Central European periphery, and second, to contribute to the broader debate on the mechanisms and factors of upgrading of emergent economies in global production networks.

The international expansion of domestic-owned automotive firms and a resulting emergence of new multinationals is discussed herein combining the perspectives and interpretations of global production networks noted earlier and the evolutionary (dynamic) approach (outlook). The results may also help in better understanding of evolutionary resilience of semi-peripheral regions, from which the studies companies originated-underlying the factor of dynamic localized capabilities.

The research combines quantitative and qualitative research methods. To discuss the evolving position of the Polish automotive industry in the European context, the data was acquired from the Eurostat databases: Structural business statistics database (sbs) on employment in the automotive industry and International Trade in Goods Statistics (ITGS) database, which was used to calculate the volume of exports and imports of automotive industry products. These Eurostat databases offer the most up to date and detailed data, which allows to catch the trends and to make comparisons between countries. Moreover, Eurostat publishes the newest available data one year earlier than most national statistical offices, including the Polish Statistical Office. On the author's unique multiattribute database of the automotive industry in Poland at a plant level (818 companies, including 273 firms with domestic capital), a group of eight companies with Polish capital that have undertaken international expansion was tracked. Four companies with the largest scale of internationalization were selected from this group as case studies. Next, publicly available sources of information with regard to operations of these companies for the period 2000-2020 were systematically queried. The dominant data sources include annual financial statements of the companies and reports of the management boards, press releases and interviews with company managers. Each of these enterprises is a publicly listed company with an obligation to provide access to relevant information on its operations. Therefore, 
the publicly available annual reports, rich in detailed information, are primary and reliable source material for determining, among other things, the business strategy and the factors influencing its operations. An understanding of the motivations of the companies and the context of their internationalization was provided by semi-structured interviews with CEOs or other high-rank managers of the studied companies (three interviews), deputy directors of automotive clusters (two interviews) and heads of special economic zones and regional development agencies (five interviews). These interviews have been a part of a larger research projects carried out by the authors, which comprised so-far more than 100 semistructured interviews with stakeholders involved in the automotive industry ecosystem in Poland and Central Europe and conducted between the years 2005 and 2020 [10-13]. The semi-structured interviews (11-15 open questions depending on the type of respondent, either company or business support institution) lasted on average 60-120 min and were recorded (provided that explicit consent was expressed) and transcribed. Additionally, three shorter interviews were conducted with managers of the companies during their participation in industry conferences and industrial fairs. All interviews were conducted over two time periods: 2005-2007 (four interviews) and 2018-2020 (remaining ones). The first round of interviews enabled to capture the mechanism of analyzed companies growth and upgrading prior to major phase of their international expansion, while the latter explicitly deals with the factors of upgrading and limits of internationalization of automotive companies with domestic capital. Research on company strategies and expansion originated from other automotive semi-peripheral countries (e.g., Spain) is used as a reference case.

\section{Literature Review}

\subsection{Conceptual Background}

In the paper, we combine three theoretical insights in order to discuss and interpret mechanisms of development of new multinationals. First, we start with positioning the paper within the core-periphery model. Second, we move on to global production networks and attempt to combine it with dynamically localized capabilities. Third, we introduce firmspecific and country-specific advantages in order to provide the theoretical background for an increasing number of TNCs from emerging economies. Ultimately, based on existing literature we discuss the position of post-communist semi-peripheral Central Europe in the context of development of new multinationals in the automotive industry.

There is a continuous debate on core-periphery relationships and their stability and/or change over time. Opportunities for the upgrading of the position of the periphery in global production networks (global value chains) are a particularly contentious issue. The role of transnational corporations (TNCs) is seen as vital in the so-called new international division of labour, where some newly industrializing economies become labor-intensive export platforms through foreign investment [14]. However, there is still scarcity of research on new multinational companies originating from non-core countries.

Until recently, the growth and upgrading of automotive industry have been mainly studied [15] from the perspective of global value chains (GVC) [16,17], which provides a perspective on the dynamics of core-periphery relationships and opportunities for upgrading of national and/or regional economies to higher value-added processes. Even if GVC concept is attempted to be applied from regional perspective [15], it may be replaced by a more nuanced, less firm-centric view, which involves institutions and other non-firm stakeholders (local authorities, development agencies, labor unions, business associations, supranational organizations, and even consumers) $[18,19]$ as key players which shape regions. Hence, in order to frame our case studies, we use the global production networks approach (GPN) [19]. We follow GPN framework as its focal element is the "strategic coupling" between GPNs and regional (national) assets [20] and uneven distribution of power. The possibilities for upgrading in peripheral regions may occur through the coupling of local, regional, and national assets with the strategic needs of TNCs $[19,21]$. 
We follow the understanding of global production networks developed by so-called "Manchester School" of economic geographers [18,19]. From GPN perspective, three types of "strategic coupling" have been distinguished [22]: functional (taking the form of international partnership with divided competences, roughly equal and mutually beneficial linkages between local and global partners), organic (indigenous innovation and the idea of promoting the rise of regional enterprises to global success through accompanied regional policies), and structural (production platforms with strongly asymmetrical power relations at the expense of local actors and weak locally integration of GPN) [20]. Coupling in production platforms has been as fragile and weakly strategic in nature as it stems from continuous public efforts to attract global investors.

We argue economic development may be a product of "strategic coupling" between GPNs and regional or national assets, the process through which "strategic interests between local actors and their counterparts in the global economy" are coordinated and mediated [23] (p. 213). This process is also interpreted in terms of dynamic localized capabilities created, reproduced, enhanced, or eroded through an interplay of foreign and domestic firms' business activity, local labour force, and institutions. Localized capabilities include the skills and attitudes of workers, managers, and entrepreneurs, as well as the reliability of suppliers and various public and private institutions, underlain by broader institutional structures [10]. Localized capabilities can foster upgrading and the embeddedness of GPNs in a particular territory.

The automotive industry is a prominent sector of high-volume production, including sophisticated components and relatively simple labor-intensive ones. The experience of formerly peripheral economies, which are regarded as part of the industrial core now, such as South Korea and Spain [24,25] is particularly interesting here. Their enhanced role was associated with the rise of local TNCs successfully expanding into global markets. There is now a growing number of TNCs from emerging economies, e.g., China, Mexico, Brazil, and Turkey, successfully doing business in the global market [26]. This emerging pattern may be explained via two key concepts.

The first is the concept of ownership advantages [27], referred to also as firm-specific advantages (FSA) [28]. These underscore the importance of company capabilities, such as economies of scale, human capital, patents, brands, and key business linkages, including company involvement and position in the value chain. However, these aspects reflect rather the advantages of companies from the core and are less useful in explaining the success of TNCs from emerging markets [29]. Therefore, a second approach was developed, which claims it is necessary to take into account country-specific advantages (CSA), i.e., the ability to accumulate both capital and knowledge from inward FDI [30], favorable macroeconomic circumstances, e.g., interest rates and exchange rates, national systems of innovation [31], and government policies and regulations [21,32,33]. More and more scholars advocate to combine both approaches (FSA and CSA) to explain the success of TNCs originating from some emerging economies [34,35]. Following this line of thinking, Biggart and Guillen [24], in their study of the automotive industry in South Korea, Taiwan, Spain, and Argentina show that there are no universal development paths, as these are shaped by vital relationships between a country's historically formed patterns of social organization and opportunities present in global markets. For example, both strong patrimonialism with high tariffs for assembled cars and incentives for exports helped to create large industrial "chaebols" in South Korea. At the same time, a lack of tariffs on car components hindered the emergence of strong Tier-1 domestic suppliers and for a long time the South Korean automotive industry was technologically dependent on suppliers from abroad.

The interesting emergence of new multinationals has been observed also in the case of the Spanish enterprises. In the 1970s and 1980s the country's automotive sector became dominated by foreign companies. Still, some Spanish companies did survive and had a chance to grow with their foreign partners and are now important global suppliers of automotive components. Foreign assemblers invested in existing and new facilities and looked for suppliers that were able to meet specific quality and quantity requirements. Most 
domestic firms in Spain did not pass this test [36], but some were successful, becoming local Tier-1 suppliers, e.g., Grupo Antolin, Gestamp, CIE Automotive, Ficosa, and Zanini. As family firms, Spanish component producers in the late 1990s searched for external financial support thorough joint ventures or selling their stock in order to speed up their expansion. The adoption of the euro currency helped the strongest Spanish companies become truly multinational [37]. The development of R\&D capacities and the model of organic strategic coupling was a prerequisite to become a Tier- 1 supplier. Next growth trigger of the Spanish multinationals was the economic crisis of 2008. Both Gestamp and Grupo Antolin decided to grow further through acquisitions and geographical diversification, despite market uncertainty and the necessity to go deeper into debt. During this period, not only mediumsize companies, but even large German automotive suppliers were subject to takeovers, e.g., ThyssenKrupp Metal Forming and EDSCHA. Guillén and Garcia-Canal [37] summarize the development path of new multinationals by stating they possess better political and organizational capabilities. Moreover, TNCs from emerging countries are more willing to establish joint ventures and alliances or grow through acquisitions.

\subsection{Central European Studies of the Automotive Industry}

The position of post-communist Central Europe is well summarized by Coe [38] (p. 100) who argues the fast economic growth of these countries since the 1990s "necessitates further adjustments to frames of understanding and interpretation". On the one hand, the $\mathrm{CE}$ region may be seen as dependent market economy [39]. Its economic success is based on a combination of skilled, but relatively cheap, labour and the provision of capital and innovation within TNCs. However, such a comparative advantage may not be sustainable in the long run, and may become eroded by a diminishing pool of skilled labour and relocation of TNC production elsewhere. Novotny et al. [40] (p. 16) claim that "productivity differentials suggest that Czech manufacturing [ ... ] has adopted a specific and semi-peripheral position in the European economy". Geodecki and Grodzicki [41] note the unfavorable competitive position of $\mathrm{CE}$ manufacturing in global value chains. Similarly, in a recent study on the CE automotive industry, Pavlínek [42] (p. 2) argues that the region's upgrading "is unlikely to alter its peripheral position in the European automotive industry division of labour". This is very much due to foreign control of the sector, which "will possibly limit the industry's potential for future economic development and for closing the gap between CE and Western European economies". Thus, CE may represent a case of "truncated development" $[43,44]$ and the syndrome of a "branch-plant economy" dominated by foreign-owned subsidiaries that are not strongly embedded in the local economy, possess few local linkages, and may be relocated to other low-cost areas of the world at any time. As a result, participation in global production networks does not in itself guarantee optimal conditions for endogenous growth and upgrading.

On the basis of their studies in the Czech Republic and Slovakia, Pavlínek and Ženka [45] argue that external ownership makes it less likely that higher value-added activities will be developed in peripheral countries and regions. Domestic automotive suppliers are relegated to the bottom of the supplier hierarchy, which translates into the production of simple, low value-added, standardized, and slow-changing components. They suggest that "GVC/GPN perspectives seem to be unduly optimistic because firm-level upgrading, especially among domestic firms, has mostly been limited to process upgrading [... ]. Examples of successful strategic couplings in the ECE automotive industry are an exception rather than a rule, while the newly developed dependence on foreign capital and truncation effects are widespread" [46] (p. 578).

On the other hand, there are studies showing the movement of CE upwards from its historically peripheral position through the development of new capabilities, which manifests itself especially in increasing exports of high value-added products. Traditional branch plants may be transformed into "performance/networked branch plants" and/or may possibly gain a "product mandate" with broader functions and competencies within a TNC [44,47]. Significant industrial upgrading means that CE has become a semi-periphery 
of the Western European core characterized by a mix of higher and lower value-added goods $[11,48]$. There is much less evidence for the process of functional upgrading in CE industrial activities, that is the development of design and marketing capabilities by foreign subsidiaries and domestic companies.

\section{Basics of the Central European and Polish Automotive Industry}

The automotive industry has become one of the main sectors of Central European economies in recent decades. This was largely fueled by a massive inflow of FDI and resulted in the integration of CE into Europe-wide automotive production networks, which is illustrated by growing passenger car production and spectacular growth of automotive exports (Figure 1). Slovakia is now the world's leading passenger car maker in relative terms, with 196 vehicles manufactured per 1000 inhabitants, overtaking the Czech Republic (134), Slovenia (96) and Germany (56) [49,50]. Poland is the largest manufacturer of buses and coaches in the EU, whereas Hungary is the second largest producer of car engines in Europe after Germany, and the largest car engine exporter in the EU. Motor vehicles and automotive components represent $23-25 \%$ of total exports of Hungary, the Czech Republic, and Romania, and as much as $33 \%$ of exports of Slovakia, which is significantly more than in the case of Germany (19\%), where the automotive sector is seen as one of the pillars of the national economy. In the case of Poland, which is characterized by a much larger and more diversified economy than other $\mathrm{CE}$ countries, the share of automotive exports is $15 \%$. The expansion of the sector in CE also finds expression in terms of employment. In 2018 more than one in four jobs in the automotive industry in the EU was found in six CE countries (790,000 out of 2,742,000 employees). Employment in the CE automotive sector has doubled since 2004. Poland with more than 214,600 employees has become the third largest country in this respect in the EU after Germany $(917,000)$ and France $(238,000)[51]$.

The fundamental factors underlying the involvement of foreign TNCs and the growth of the automotive sector in CE have been lower labour costs combined with the availability of a well-educated, skilled workforce and geographical proximity to the Western European production core. These strengths are supplemented with the institutional stability provided by EU membership and to some extent by various government incentives $[11,42,52,53]$.

The size and diversified structure of the automotive industry in Poland is shown by its exports (Figure 2). Similarly, as with other Central European countries, Poland has achieved an increasing surplus in its automotive trade with the core economies of Western Europe, exceeding 7.1 billion euro in 2019. There are passenger car and LCV assembly plants in Tychy (FCA), Gliwice (Opel/Peugeot), Poznań and Września (Volkswagen), bus and truck factories (Solaris, Volvo, Scania, MAN), large engine plants (Toyota, Volkswagen, Opel/Peugeot, FCA, Mercedes), and manufacturing facilities of all sorts of components. More than 350 large and medium-size greenfield plants were built in the country in the post-socialist era. Altogether, there were 750 automotive plants in Poland with valid IATF 16,949 quality certificates as of 31 December 2019 . One-fourth $(24.8 \%)$ were domestically owned, which confirms the dominance of foreign producers that have built the majority of new factories and have taken over older factories. The share of domestic manufacturers in employment was even lower (20\%) as most of them are medium-size companies.

All of these facets make Poland a very interesting case study of industrial upgrading in the automotive industry and the expansion of domestic firms in global markets in particular. 


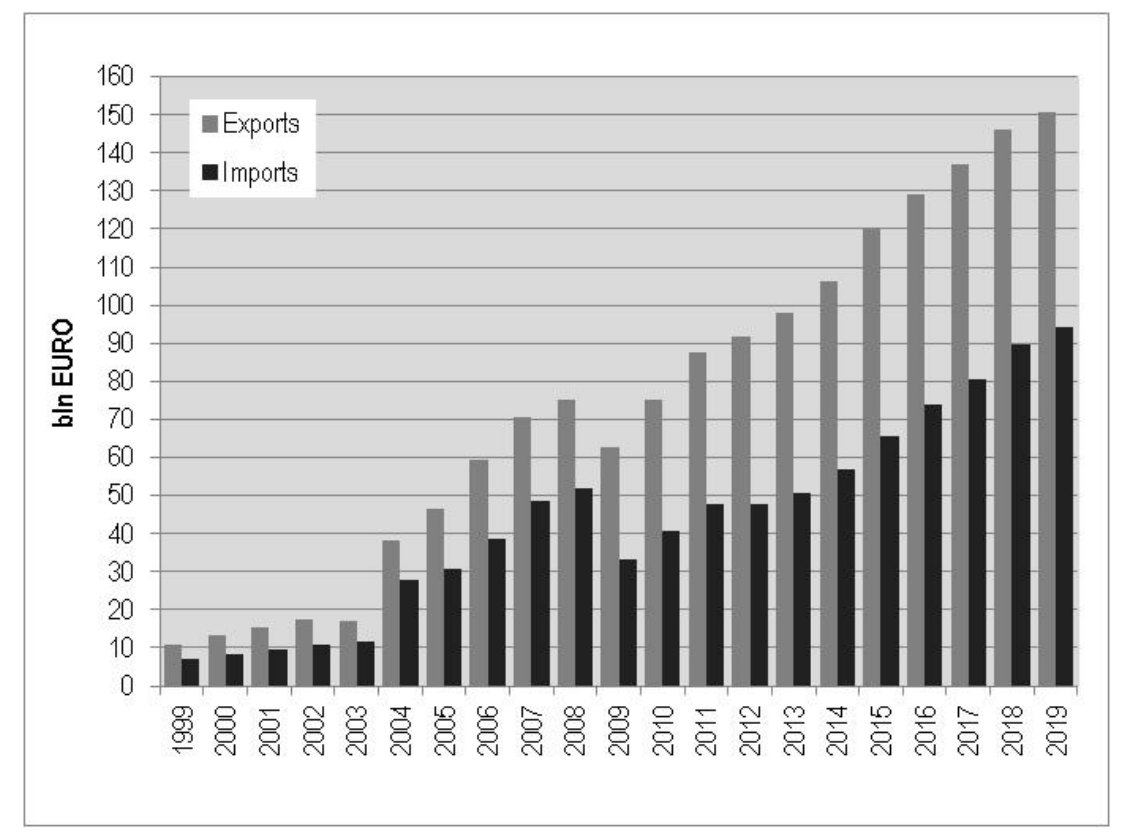

Figure 1. Dynamics of automotive exports and imports of Central European countries 1999-2019. Source: authors' elaboration based on Eurostat data [54].

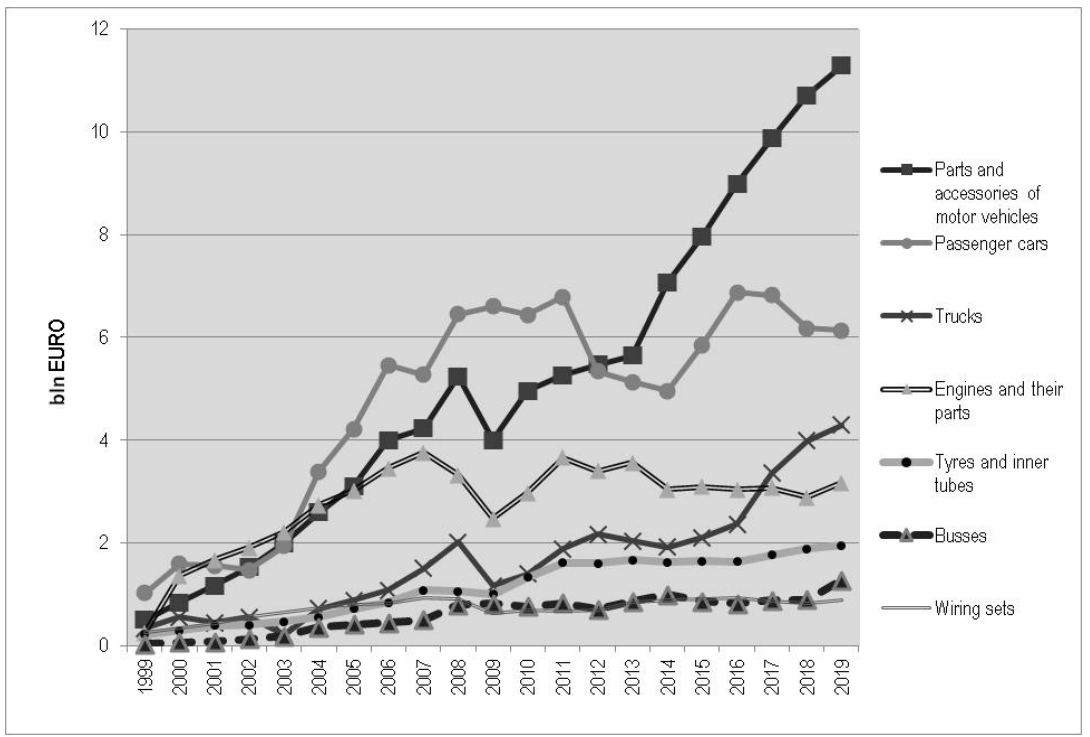

Figure 2. Dynamics of Polish automotive exports 1999-2019. Source: authors' elaboration based on Eurostat data [54].

\section{Results: Polish Automotive Companies Going Global-Case Studies}

The international expansion of Polish manufacturing firms has been observed in various sectors since the late 1990s. It began primarily as greenfield investment in PostSoviet countries, mostly Ukraine, and was followed by mergers and acquisitions in the new Central European members of the EU. Thus, the common feature of the majority of Polish outward FDI (8.2 billion USD in 2016) was its market-seeking nature and geographical concentration in the post-socialist economies of Central Europe [55-57]. One of the best examples of such expansion is Maspex, which took over several leading food and drink producers in the Czech Republic, Slovakia, Hungary, Romania, Bulgaria, Lithuania, and Latvia. The company produces juices, nectars, and non-carbonated soft drinks, pasta, cereal and instant products, and jams and preserves at 15 plants, with sales revenues reaching 1.3 billion USD in 2018 . 
In the automotive industry, the growth of domestic producers and their success in international markets for a long time meant increasing exports from enlarged factories at home. This was for example the case with Solaris, which developed as a major European manufacturer of city buses and one of the leaders in the production of hybrid and electric vehicles, in particular. It began with small-scale assembly for the domestic market, but quite early adopted a risky strategy of making high-quality low-emission buses designed for the general European market. Solaris became the first serial manufacturer of hybrid buses in Europe and launched production of fully electric buses in 2015 [58]. However, three years later the company was sold to Spanish CAF.

Groclin appeared as a forerunner of Polish automotive outward FDI (Table 1). The company developed from a small workshop established in the town of Grodzisk Wielkopolski near Poznań in 1977. It became a supplier of car seat bolsters for the state-owned assembly plants of FSO in Warsaw and FSM in Tychy in the 1980s and was transformed into a joint venture with a minority German partner in 1991. The takeover of Polish OEMs by foreign investors (FSM by Fiat and FSO by Daewoo), which brought their own seat suppliers, forced a new strategy for Groclin. It began to specialize in the production of labor-intensive seat covers, especially those made of natural leather, as a Tier-2 subcontractor of Johnson Controls, Lear, Faurecia, and others. The company has been listed on the Warsaw Stock Exchange since 1998 and was controlled by its founder, Zbigniew Drzymała, with no foreign capital. Seeking cost reductions, Groclin built a greenfield plant in Uzhorod in Ukraine in 2004. In 2007 it was the largest Polish-owned automotive supplier with 3870 employees in 3 factories in Poland and 1 in Ukraine (plus another one under construction in Dolyna) and revenues of about 170 million USD.

Table 1. Characteristics of the discussed Polish multinational automotive companies in 2019.

\begin{tabular}{|c|c|c|c|c|}
\hline Name & Boryszew & Wielton & Sanok Rubber & Groclin \\
\hline Headquarters & Warsaw & Wieluń & Sanok & Grodzisk Wielkopolski \\
\hline $\begin{array}{c}\text { Automotive } \\
\text { manufacturing plants }\end{array}$ & 20 & 8 & 5 & 3 \\
\hline Automotive R\&D sites & 3 & 4 & 2 & 2 \\
\hline Main products & $\begin{array}{l}\text { hydraulic break hoses } \\
\text { and air conditioning } \\
\text { conduits; plastic } \\
\text { elements (i.e., lockers, } \\
\text { cockpits, handles, } \\
\text { engine covers) }\end{array}$ & $\begin{array}{l}\text { trailers, semi-trailers, } \\
\text { truck bodies }\end{array}$ & $\begin{array}{l}\text { anti-vibration } \\
\text { compounds and car } \\
\text { body sealing systems }\end{array}$ & $\begin{array}{l}\text { seat covers and } \\
\text { complete seats }\end{array}$ \\
\hline $\begin{array}{l}\text { Total revenues } \\
\text { (USD millions) }\end{array}$ & 1648 & 617 & 283 & 31 \\
\hline $\begin{array}{l}\text { Share of automotive in } \\
\text { revenues of } \\
\text { the capital group }\end{array}$ & 31 & 95 & 60 & 100 \\
\hline $\begin{array}{c}\text { Share of revenues } \\
\text { outside Poland }\end{array}$ & $78^{\mathrm{A}}$ & 49 & 28 & 27 \\
\hline Total employment & 11,154 & 2953 & 3381 & 497 \\
\hline
\end{tabular}

A only automotive division of the capital group. Source: authors' compilation based on annual company reports of analyzed companies.

Political crisis and ensuing uncertainty in Ukraine in 2008 together with the global financial crisis led to decreasing orders for Groclin, which lost contracts for the premium segment of Volvo, Porsche, and BMW, in particular. In 2013 the indebted company merged with Kabel Technik Polska. The company's German owner, André Gerstner, who began as a manufacturer of wire harnesses, and now lives in Poznań, quickly sold his wiring business to the Finnish PKC Group, focusing on cost and debt reduction at Groclin and increasing the share of R\&D services. The latter goal has been pursued via acquisitions of small Polish and 
German engineering firms specializing in the design of car interiors. In the context of growing labour costs in Poland, the production of seat covers was gradually relocated to Ukrainian plant, while two Polish factories were sold, including the home plant located in Grodzisk Wielkopolski to a furniture manufacturer. Production activity was largely concentrated in Ukraine with reduced employment of 500 people and revenues of 31 million USD in 2019. In 2020 the company announced it decided to sell its production facilities.

Sanok Rubber is one of few older automotive suppliers in Poland which is controlled by domestic capital now. It was established in the medium-size town of Sanok in southeastern Poland in 1931 and nationalized after World War Two. As one of the first automotive firms, it was privatized by an American equity fund in 1993 and listed on the Warsaw Stock Exchange in 1997. Its international expansion began quite early with a joint venture in rubber production for the construction sector in Russia in 1995. In 2003 a management buyout took place. The company decided to invest more in the automotive segment, the share of which reaches $60 \%$ now. Its 2014 takeover of the German manufacturer of sealing systems, Draftex Automotive, supplying BMW and Audi among others, was a vital step in this strategy. This was followed by the acquisition of a French producer of belts and couplings, Colmant Cuvelier RPS (CCRPS), in 2015 as well as Qingdao Masters of Rubber and Plastic in China in 2016, which opened up new markets in France, North Africa, and the Far East. Sanok's construction of a greenfield plant in Mexico in 2018 meant entering the NAFTA market. Sanok Rubber Group now employs about 3200 people in its automotive factories specializing mainly in sealing and anti-vibration systems in 5 countries. It is a Tier-1 supplier for several OEMs (60\% of automotive sales), the share of none of which exceeds $10 \%$, and Tier- 2 in the remaining part of its business. It has R\&D centers in Sanok and Grefrathin (Germany) and two plants making non-automotive products in Russia and Belarus. Its total revenues are about 280 million USD.

By contrast, Boryszew is a relative newcomer in Poland's growing automotive sector. The name of the company comes from a small locality east of Warsaw, where a factory of art silk was built in 1911. The factory began to produce antifreeze and brake fluids after 1945, was privatized in 1992, and listed on the stock exchange 4 years later. Since 2000 it is part of a large industrial group controlled by Roman Karkosik and specializes in industrial chemicals and non-ferrous metals, including synthetic fibers and aluminum. In the aftermath of the global financial crisis of 2008-2009, the Boryszew Group decided to establish an automotive division as part of its diversification strategy, taking advantage of the opportunity to take over ailing manufacturers. It acquired Italian Maflow with 7 plants making aluminum and rubber tubes, four medium-size German producers of automotive plastic components and tooling as well as Japanese Tensho subsidiaries located in Poland and Germany between 2010 and 2014. Furthermore, following new investments of Volkswagen as its major customer, 5 greenfield plants were built by Boryszew in India (2011), Russia (2014), Mexico (2016), and Poland and Germany (2017). As a result, it now owns 20 automotive component factories in 11 countries including France, Spain, the Czech Republic, Brazil, and China together with R\&D centers situated in Italy, Germany, and Poland (Figure 3). Sales by its automotive division exceeded 500 million USD and turnover of the entire Boryszew group was 1650 million USD with employment at 11,154 in 2019.

The question is whether Boryszew's involvement in the automotive sector is really a long-term strategy of the group or rather a medium-term investment meant to provide a return for its shareholders. Boryszew has sold off some of its industrial companies in the past and announced the sale of its aluminum rolling mill to a Swedish corporation in 2020. 


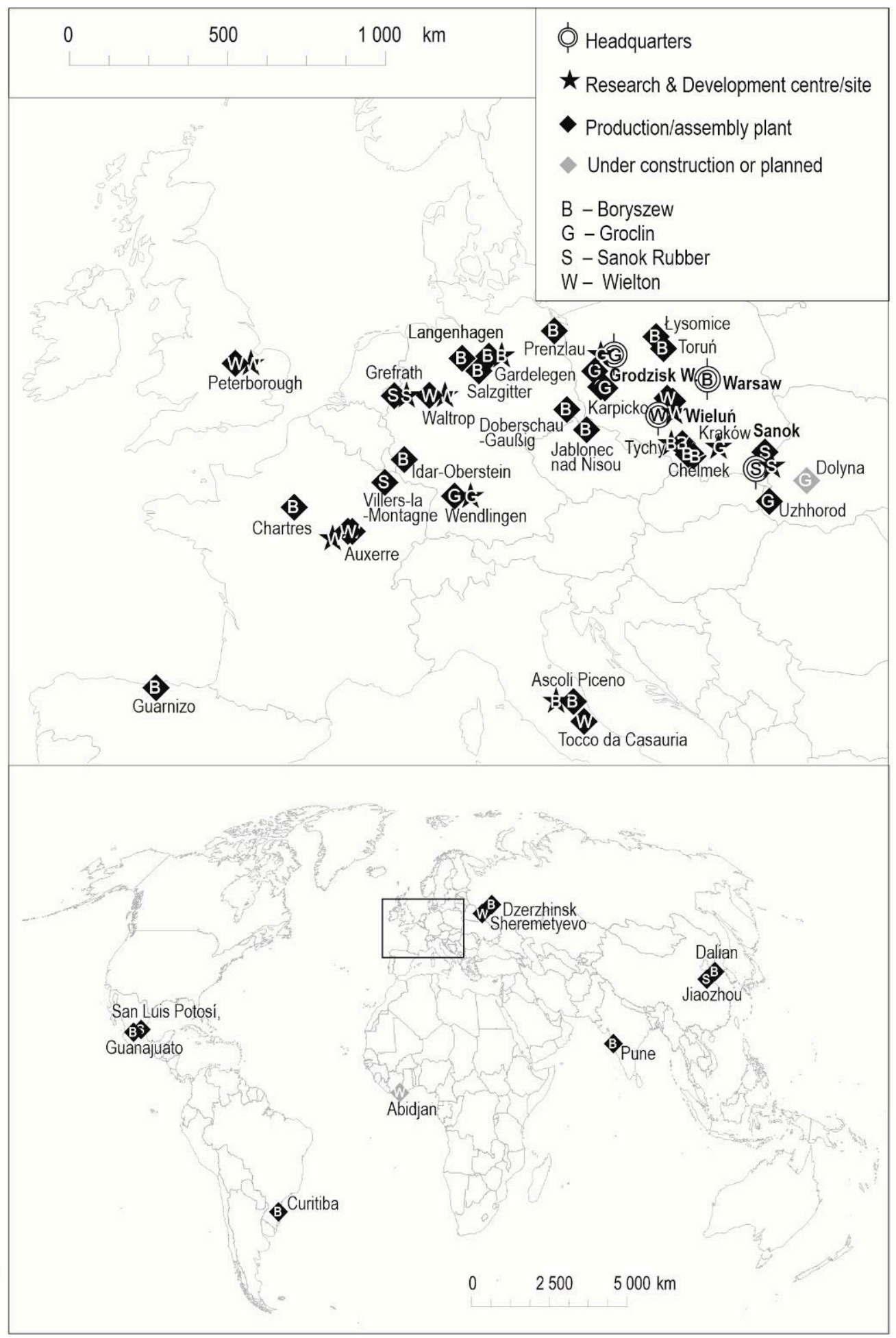

Figure 3. Automotive factories and R\&D centers of Wielton, Boryszew, Sanok Rubber, and Groclin. Source: authors' elaboration based on annual company reports of analyzed companies.

A different path of organic growth of a private enterprise is represented by Wielton. It was established in 1990 as a company repairing second-hand semi-trailers imported from Western Europe and adjusting them for the Polish market. In 1996 it began production of semi-trailers for the domestic market. Its subsequent growth was underlain by huge demand in Poland and Central Europe, due to the spectacular success of transportation firms from this part of Europe. Polish carriers are now leaders in road transport in the 
European Union with more than 25 per cent share of the market, and Poland has the largest modern fleet of trucks in the EU.

Wielton's comparative advantage was based on a combination of relatively low prices, high quality, and flexibility. The company was ready to provide a broad range of products adjusted to the needs of many different medium-size customers. It has raised capital through the Warsaw Stock Exchange since 2008. A Wielton assembly plant was opened near Moscow in 2012 as part of a plan of further expansion in the Post-Soviet markets of Russia, Ukraine, and Belarus.

The Ukraine political crisis following the annexation of Crimea by Russia encouraged a radical revision of Wielton's strategy towards Western European markets. The company decided to build its market position through acquisitions of strong, local brands owned by its competitors. In 2015 it took over Fruehauf in France and Rimorchi (with Merker, Cardi, and Viberti brands) in Italy. This was followed by the acquisition of Langendorf in Germany in 2017, which made Wielton the third largest manufacturer of semi-trailers in Europe after Schmitz and Krone, and one of the top ten global producers. After the purchase of Lawrence David in the UK in 2018, Wielton operated 8 manufacturing plants and 4 R\&D centers (including Auxerre in France and Waltrop in Germany) in six countries (Figure 3) as well as service centers in 28 countries with turnover at 617 million USD and 2953 employees in 2019. The company has plans for the construction of an assembly plant in the Ivory Coast in West Africa.

There are several other producers of automotive components that have acquired and/or built one or two greenfield plants abroad. For example, Alumetal, which started as a state-owned enterprise in 1953, is now one of the largest European manufacturers of secondary aluminum casting alloys with $90 \%$ of sales to the automotive sector (450 million USD in 2018) with 3 plants in Poland and one plant in Hungary. In contrast, Izoblok, specialising in the production of expanded polypropylene (EPP) molded parts was established as a private firm in 1998. It was taken over by a foreign investor in 2003, but a few years later the Polish founder and minority shareholder regained control of the firm, and in 2016 acquired $100 \%$ of the shares of the German company SSW PearlFoam, thus becoming a leader in the European EPP market.

\section{Discussion}

The global expansion of Polish automotive manufacturers is a relatively recent trend that started around 2010 and gained momentum between 2015 and 2018. It was preceded by an organic growth of companies beginning as suppliers for foreign TNCs and/or leaders in the domestic market. Their early international expansion was directed towards Eastern Europe as a market for their products (Wielton, Sanok Rubber) or low-cost manufacturing location (Groclin). Early expansion towards Eastern Europe followed the model of export (production) platforms. With expected weak local linkages it should identified as structural strategic coupling. The geographical shift to Western Europe and non-European markets was related to a change in the motivation for foreign investment. Market expansion in the core economies of Western Europe and follow-the-client strategy in the emerging economies of Asia and Latin America came to the forefront instead of the cost-motives of FDI. This reflects a new ambition of seeking a prominent or even leading position, especially in selected niche and/or labor-intensive products. What appears to be a precondition for going global is earlier success in reaching a strong position in the domestic and/or Central European market, which lay at the root of gradually built self-confidence, and hence corresponds with the model of staged development of internationalization.

Expansion occurred to a great degree through foreign acquisitions in core countries. This was possible due to financial capabilities related to earlier success, capital raised on the stock exchange, involvement in other industries (Boryszew, Sanok Rubber), and/or former foreign (co)owners. Expansion was accompanied by greenfield investment following TNC clients in emerging economies and occasionally in core countries. 
The growth of domestic manufacturers has been underlain by a broader transformation of Central European economies since 1989, which yielded a large, diversified manufacturing base, dominated by foreign subsidiaries in selected sectors, e.g., automotive industry, and the development of numerous small and medium-size domestic firms. CE industry is characterized by advanced manufacturing capabilities as well as strong integration with Western European production networks, but relatively limited non-production competences. The relatively large size of the market in Poland and in Central Europe as a whole, together with its continuous development and consequent economic growth, made room for the expansion of local CE companies. What is also important is their situation in the stable institutional setting of the European Union since 2004. Massive public investment in physical infrastructure including new roads making up for Poland's underdevelopment in the socialist era and assisted by EU funds, also helped drive fast economic growth throughout the country and the emergence of transport companies, which created a market for companies, such as Wielton. Interestingly enough, there was no government policy supporting large Polish-owned firms in contrast to strong incentives attracting mainly foreign investors to Polish special economic zones. Hence, due to the lack of involvement of government authorities there was very limited organic-driven coupling, but rather a mix of functional and structural strategic coupling. All things considered, the international expansion of automotive firms from Central Europe may be interpreted using the evolutionary perspective as a specific critical conjuncture of three mechanisms (Figure 4):

- rapid development of Central European economies since the end of communism (leading to establishment of country-specific advantages),

- the evolution of the Western European core, especially since the dire effects of the global financial crisis of 2008-2009,

- the strategies of individual Polish firms (resulting in firm-specific advantages).

Hence, we argue the conjuncture of firm-specific and country-specific advantages lead to the expansion of the Polish new multinational automotive enterprises. In this respect, we combined two approaches (FSA and CSA) what has been advocated to explain the success of TNCs originating from emerging economies [34,35].

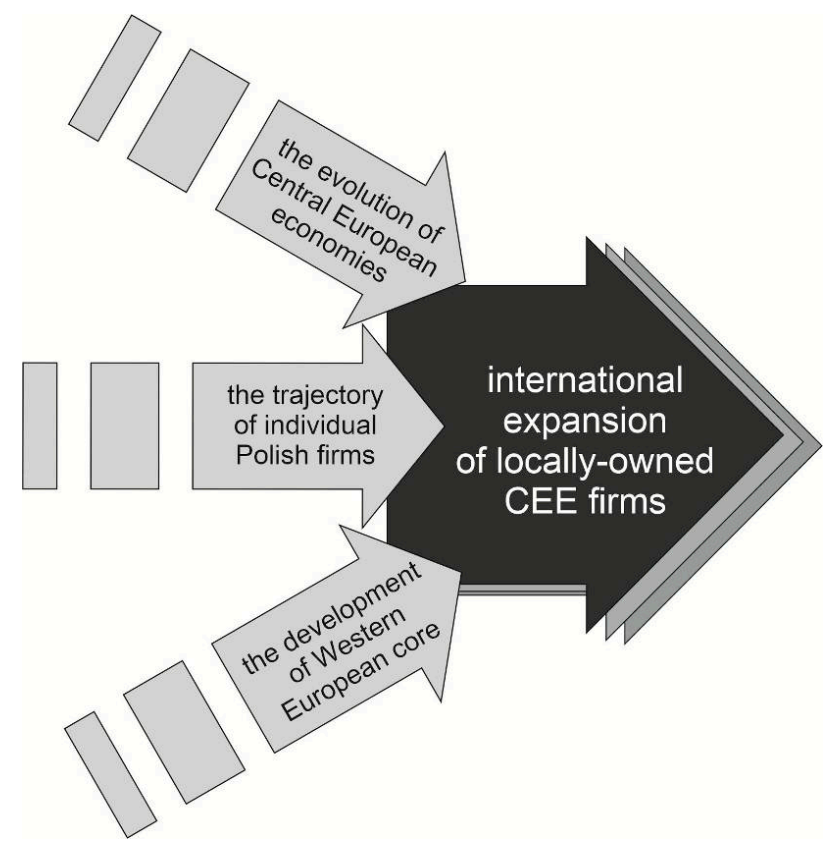

Figure 4. The critical conjuncture of three mechanisms giving rise to global expansion of Polish automotive firms. Source: authors' elaboration. 
The strategies of the discussed firms going global cannot be understood without taking into account the critical interdependence between firm-specific capabilities and countryspecific advantages and regional specific-advantages. The dynamic relationship between the features of firms and their strategies on the one hand and the changing characteristics of the territory on the other gave emerging Polish multinationals high organizational adaptability as well as lowered their risk aversion, due to their experience with operating in difficult and rapidly changing environments, fast growth, and the permanent need to remodel their structures. The combination of traditional cost advantages with greater flexibility allowed them to identify the window of opportunity, which appeared in the aftermath of the financial crisis and sowed the seeds of ambition to take advantage of this opportunity. This may be interpreted in terms of dynamic localized capabilities and strategic coupling between regional assets and global production networks also seen and interpreted in terms of evolutionary economic resilience of both regions and companies. There are some similarities to the development of Spanish component manufacturers that joined global production networks a few decades earlier [36-39].

The Spanish case is similar to the strategies of Polish companies. However, differences are also evident - the size and role of Spanish companies in automotive production networks, based on a much longer collaboration with and greater trust in main OEMs, as well as easier access to the financing of the internationalization process (longer tradition of financial discipline), and foremost earlier experience of global expansion are important differentiating elements.

When it comes to the contribution to an academic debate on the role of new multinationals, the international expansion of companies from Central Europe can be seen as part of a broader process of changing geography of the automotive industry with a major shift from the historical core (developed countries) to the periphery (emerging countries). In particular, this may be an important mechanism of catching-up and upgrading for companies and countries of the periphery and reflects the changing geometry of power of firms discussed recently by Covarrubias and Ramírez Perez [59].

\section{Conclusions}

The main strand of literature focuses on the domination of foreign TNCs various peripheral and semi-peripheral countries, whereas the international expansion of domesticowned enterprises is neglected. The Polish case should be of specific importance, due to Poland's inferior position in global production networks and the absence of an active industrial policy towards domestic companies during the long transformation period after 1989. The literature lacks an in-depth discussion of such a context of company internationalization. It is also the novelty to combine various concepts of: country(regional)specific advantages, "strategic coupling", localized capabilities, and industrial upgrading. What is also uncommon, it is the application of above-mentioned constructs to discuss the emergence of new multinational companies in integrated peripheries of Europe.

There are at least two major limitations of the study. First, there were not any conducted interviews in foreign subsidiaries of the analyzed companied. Hence, the position of new multinationals in GPNs cannot be fully revealed. Second, relatively short time of internationalization of the Polish firms means it is too early to capture the long-term effects of foreign expansion. Hence, operations of new multinationals and their impact should be furthermore observed.

Concerning the main aim of the paper, the vital question is to what extent and how the global expansion of some domestic companies affects the position of the Polish automotive industry in global production networks. The outcome is shaped by evolving power of studied companies within GPN, and turbulent dynamics of firm-specific and countryspecific advantages varying in, and due to, the pandemic period.

The immediate effect is that manufacturers from the EU's periphery achieve a stronger market position with brand names and distribution networks (e.g., Wielton) they control in the core economies of Western Europe and emerging economies of Asia and Latin America. They gain more power in global production networks by taking a step forward from a 
comparative advantage based primarily on low labour costs (exemplified by the failed strategy of Groclin) towards enhanced non-production competences via functional upgrading. Furthermore, peripheral manufacturers escape the vicious circle of low economies of scale and lack of decision-making, marketing, and design capabilities, which have hindered their upgrading in global production networks thus far. This is especially important in the case of companies from Central Europe, regarded as dependent market economies, which relied on capital and innovation/technologies provided by TNCs from core countries, and the growth of which was considered a form of truncated development and branch plant economy syndrome. As domestically owned firms usually tend to source more components and non-production services locally than foreign subsidiaries in Central Europe [45], this may also lead to further growth in the supplier sector at home and give some domestic suppliers access to new foreign markets following their Polish-owned customers.

At the same time, the number of firms successfully expanding in international markets and their size (e.g., none of them are among the 100 world's largest automotive suppliers) are still limited, which means their current impact on the automotive sector in Poland is rather modest. The effects of the acquisition of Western European companies on the development of non-production competences can vary. On the one hand, this may enhance the technological capabilities of Polish manufacturers through the transfer of know-how and personnel, but on the other hand, R\&D and design may still be carried out at Western European subsidiaries rather than in Poland. In addition, there is a risk of the failure of the subsidiaries acquired in Western Europe since many of them are companies in a difficult economic situation, which requires costly restructuring. Consequently, the automotive manufacturers from the periphery which went global face new challenges. These are of an organizational nature-managing operations in different cultural and institutional contexts in many different countries and/or on many continents. Some of the challenges are economic in nature, growing capital needs and related efficiency improvements, and some are technological - the ability to generate and adopt innovations. The next decade will show whether these new multinationals are able to cope with these challenges, among them electromobility transition, and hence maintain and/or further improve their position in global production networks, as what H. Simon [60] calls mid-size world market leaders or even lead firms in some market niches. The open question is the further evolution of technologies in renewable energy and development of EV's sector that is still in its infancy stage. In this respect various scenarios are still possible and ability of European automotive industry to bridge the gap with their Asian competitors may reshape the industry. And the black scenario here is of erasing its spatio-temporal fixes [61] with more profound changes and potentially more negative consequences impacting so called integrated peripheries [6], negatively exposing their adaptability and regional resilience. Last but not least, there is always the threat of a foreign takeover of successful Polish firms, which is exactly what happened to the Solaris company recently.

Potential future research areas include, first, the impact of the acquisition of Western European companies with R\&D centers on knowledge transfer within the multinational and, second, the long-term effects for the European and global supply networks. For example, the question to what extent there is an attempt to integrate the historically separate supply networks of acquired companies in each country into a corporate supply network, should be addressed.

Author Contributions: Conceptualization, G.M., R.G., K.G. and B.D.; methodology, B.D., R.G. and K.G.; formal analysis, G.M., R.G., K.G. and G.M.; investigation, R.G. and K.G.; writing-original draft preparation, B.D., R.G., G.M. and K.G.; writing-review and editing, G.M. and B.D.; visualization, R.G. and K.G.; supervision, B.D.; funding acquisition, B.D, K.G., R.G. and G.M. All authors have read and agreed to the published version of the manuscript.

Funding: This research and APC were funded by Poland's National Science Center, grant number 2017/27/B/HS4/01935, Paths and limits to industrial upgrading: high- or low-road of development in Polish manufacturing. 
Institutional Review Board Statement: Not applicable.

Informed Consent Statement: Not applicable.

Data Availability Statement: Data sharing not applicable.

Conflicts of Interest: The authors declare no conflict of interest. The funders had no role in the design of the study; in the collection, analyses, or interpretation of data; in the writing of the manuscript, or in the decision to publish the results.

\section{References}

1. Hassink, R. Advancing the Understanding of Regional Economic Adaptability in a Non-Western Context: An Introduction to the Special Issue. Growth Chang. 2020, 48, 194-200. [CrossRef]

2. Martin, R.; Sunley, P. On the notion of regional economic resilience: Conceptualization and explanation. J. Econ. Geogr. 2015, 15, 1-42. [CrossRef]

3. Simmie, J.; Martin, R. The economic resilience of regions: Towards an evolutionary approach. Camb. J. Reg. Econ. Soc. 2010, 3, 27-43. [CrossRef]

4. Evenhuis, E. New directions in researching regional economic resilience and adaptation. Geogr. Compass 2017, 11, e12333. [CrossRef]

5. Hassink, R. Locked in decline? On the role of regional lock-ins in old industrial areas. In Handbook of Evolutionary Economic Geography; Boschma, R., Martin, R., Eds.; Edward Elgar: Cheltenham, UK, 2010; pp. 450-468.

6. Pavlínek, P. Restructuring and internationalization of the European automotive industry. J. Econ. Geogr. 2020, 20, 509-541. [CrossRef]

7. Mordue, G.; Sweeney, B. Neither core nor periphery: The search for competitive advantage in the automotive semi-periphery. Growth Chang. 2020, 51, 34-57. [CrossRef]

8. Sass, M. Outward FDI in the Automotive Industries of the Visegrad Countries: A Sign of Increased International Competitiveness of Indigenous Companies? In Proceedings of the International Conference on Automotive Industry 2020, Mlada Boleslav, Czech Republic, 10 November 2020.

9. Covarrubias, V.A.; Ramírez Perez, S.M. (Eds.) New Frontiers of the Automobile Industry. Exploring Geographies, Technology, and Institutional Challenges; Palgrave Macmillan: Cham, Switzerland, 2020.

10. Domański, B.; Gwosdz, K. Toward a more embedded production system? Automotive supply networks and localized capabilities in Poland. Growth Chang. 2009, 40, 452-482. [CrossRef]

11. Pavlínek, P.; Domański, B.; Guzik, R. Industrial upgrading through foreign direct investment in Central European automotive manufacturing. Eur. Urban Reg. Stud. 2009, 16, 43-63. [CrossRef]

12. Guzik, R.; Domański, B.; Gwosdz, K. Automotive industry dynamics in Central Europe. In New Frontiers of the Automobile Industry. Exploring Geographies, Technology, and Institutional Challenges; Covarrubias, A., Ramirez, S., Eds.; Palgrave Macmillan: Cham, Switzerland, 2020; pp. 377-397.

13. Gwosdz, K.; Micek, G.; Kocaj, A.; Sobala-Gwosdz, A.; Świgost-Kapocsi, A. Industry 4.0 and the prospects for domestic automotive suppliers in Poland. In The Challenge of Digital Transformation in the Automotive Industry: Jobs, Upgrading, and the Prospects for Development; Drahokoupil, J., Ed.; European Trade Union Institute: Brussels, Belgium, 2020; pp. 89-105.

14. Fröbel, F.; Heinrichs, J.; Kreye, O. The New International Division of Labor; Cambridge University Press: Cambridge, UK, 1980.

15. Rodríguez-De la Fuente, M.; Lampón, J.F. Regional upgrading within the automobile industry global value chain: The role of the domestic firms and institutions. Int. J. Automot. Technol. Manag. 2020, 20, 319-340. [CrossRef]

16. Gereffi, G. International trade and industrial upgrading in the apparel commodity chain. J. Int. Econ. 1999, 48, 37-70. [CrossRef]

17. Gereffi, G. The governance of global value chains. Rev. Int. Political Econ. 2014, 12, 78-104. [CrossRef]

18. Coe, N.M.; Dicken, P.; Hess, M. Global production networks: Realizing the potential. J. Econ. Geogr. 2008, 8, 271-295. [CrossRef]

19. Coe, N.M.; Hess, M.; Yeung, H.W.C.; Dicken, P.; Henderson, J. Globalizing regional development: A global production networks perspective. Trans. Inst. Br. Geogr. 2004, 29, 468-484. [CrossRef]

20. Yeung, H.W.C. Regional development in the global economy: A dynamic perspective of strategic coupling in global production networks. Reg. Sci. Policy Pract. 2015, 7, 1-23. [CrossRef]

21. MacKinnon, D. Beyond strategic coupling: Reassessing the firm-region nexus in global production networks. J. Econ. Geogr. 2012, 12, 227-245. [CrossRef]

22. Yeung, H.W.C. Regional development and the competitive dynamics of global production networks: An East Asian perspective. Reg. Stud. 2009, 43, 325-351. [CrossRef]

23. Yeung, H.W.C. Transnational corporations, global production networks, and urban and regional development: A geographer's perspective on multinational enterprises and the global economy. Growth Chang. 2009, 40, 197-226. [CrossRef]

24. Biggart, N.W.; Guillén, M.F. Developing difference: Social organization and the rise of the auto industries of South Korea, Taiwan, Spain, and Argentina. Am. Sociol. Rev. 1999, 64, 722-747. [CrossRef]

25. Chung, M.K. Internationalization Strategies of Korean Motor Vehicle Industry. Actes du GERPISA 1996, 18, 117-122.

26. Fleury, A.; Fleury, N.T.L. Brazilian Multinationals: Competences for Internationalization; Cambridge University Press: Cambridge, UK, 2011.

27. Dunning, J.H. Multinationals, Technology, and Competitiveness; Unwin Hyman: London, UK, 1988. 
28. Rugman, A.M.; Verbeke, A. Global Corporate Strategy and Trade Policy; Routledge: London, UK, 1990.

29. Hennart, J.F. Emerging Market Multinationals and the Theory of the Multinational Enterprise. Glob. Strategy J. 2012, 2, $168-187$. [CrossRef]

30. Criscuolo, P.; Narula, R. A novel approach to national technological accumulation and absorptive capacity: Aggregating Cohen and Levinthal. Eur. J. Dev. Res. 2008, 20, 56-73. [CrossRef]

31. Alvarez, I.; Martin, R. Entry modes and national systems of innovation. J. Int. Manag. 2010, 16, 340-353. [CrossRef]

32. Liu, Y. The dynamics of local upgrading in globalizing latecomer regions: A geographical analysis. Reg. Stud. 2017, 51, 880-893. [CrossRef]

33. Pipkin, S.; Fuentes, A. Spurred to upgrade: A review of triggers and consequences of industrial upgrading in the global value chain literature. World Dev. 2017, 98, 536-554. [CrossRef]

34. Cuervo-Cazurra, A. The multinationalization of developing country MNE: The case of multilatinas. J. Int. Manag. 2008, 14, 138-154. [CrossRef]

35. Rugman, A.M. Reconciling internalization theory and the eclectic paradigm. Multinatl. Bus. Rev. 2010, 18, 1-12. [CrossRef]

36. Guillén, M.F. The Limits of Convergence: Globalization \& Organizational Change in Argentina, South. Korea, and Spain; Princeton University Press: Princeton, NJ, USA, 2001.

37. Guillén, M.F.; Garcia-Canal, E. The New Multinationals: Spanish Firms in A Global Context; Cambridge University Press: Cambridge, MA, USA, 2010.

38. Coe, N.M. Unpacking globalization: Changing geographies of the global economy. In The Handbook of Economic Geography; Leyshon, A., Lee, R., McDowell, L., Sunley, P., Eds.; Sage: London, UK, 2011; pp. 89-101.

39. Nölke, A.; Vliegenthart, A. Enlarging the varieties of capitalism: The emergence of dependent market economies in East Central Europe. World Politics 2009, 61, 670-702. [CrossRef]

40. Novotny, J.; Blažek, J.; Kveton, V. The anatomy of difference: Comprehending the evolutionary dynamics of economic and spatial structure in the Austrian and Czech economies. Eur. Plan. Stud. 2016, 24, 788-808. [CrossRef]

41. Geodecki, T.; Grodzicki, M.J. Jak awansować w światowej lidze gospodarczej? Kraje Europy Środkowo-Wschodniej w globalnych łańcuchach wartości. Zarzadzanie Publiczne 2014, 33, 16-40. [CrossRef]

42. Pavlínek, P. Dependent Growth: Foreign Investment and the Development of the Automotive Industry in East-Central Europe; Springer: Cham, Switzerland, 2017.

43. Hayter, R. Truncation, the international firm and regional policy. Area 1982, 14, 277-282.

44. Dawley, S. Transnational corporations and local and regional development. In Handbook of Local and Regional Development; Pike, A., Rodríguez-Pose, A., Tomaney, J., Eds.; Routledge: London, UK, 2011; pp. 394-412.

45. Pavlínek, P.; Ženka, J. Value creation and value capture in the automotive industry: Empirical evidence from Czechia. Environ. Plan. A 2016, 48, 937-959. [CrossRef]

46. Pavlínek, P. Whose success? The state-foreign capital nexus and the development of the automotive industry in Slovakia. Eur. Urban Reg. Stud. 2016, 23, 571-593. [CrossRef]

47. Phelps, N.A. From branch plant economies to knowledge economies? Manufacturing industry, government policy, and economic development in Britain's old industrial regions. Environ. Plan. C Gov. Policy 2009, 27, 574-592. [CrossRef]

48. Hotopp, U.; Radosevic, S.; Bishop, K. Trade and industrial upgrading in countries of Central and Eastern Europe: Patterns of scale-and scope-based learning. Emerg. Mark. Financ. Trade 2005, 41, 20-37. [CrossRef]

49. ACEA (European Automobile Manufacturers Association). Available online: https://www.acea.be/statistics/tag/category/euproduction (accessed on 1 January 2021). data for 2019.

50. Eurostat Population (demo_pop) Database. Available online: https://appsso.eurostat.ec.europa.eu/nui/show.do?dataset= demo_pjan\&lang=en (accessed on 10 January 2021). data for 2019.

51. Eurostat, Structural Business Statistics (SBS) Database: Part: Annual Detailed Enterprise Statistics for Industry (NACE Rev. 2, B-E). Available online: https:/ / ec.europa.eu/eurostat/databrowser/view/SBS_NA_IND_R2_custom_789905/default/table?lang=en (accessed on 10 January 2021). data for 2019.

52. Radosevic, S.; Rozeik, A. Foreign Direct Investment and Restructuring in the Automotive Industry in Central and East Europe; Economics Working Paper; University College London: London, UK, 2005; p. 53.

53. Domański, B.; Guzik, R.; Gwosdz, K.; Dej, M. The crisis and beyond: The dynamics and restructuring of automotive industry in Poland. Int. J. Automot. Technol. Manag. 2013, 13, 151-166. [CrossRef]

54. Foreign Trade Data-Eurostat International Trade in Goods Statistics (ITGS) database: Part: EU Trade Since 1999 by HS2,4,6 and CN8. Available online: https://appsso.eurostat.ec.europa.eu/nui/show.do?dataset=DS-645593\&lang=en (accessed on 10 January 2021).

55. Gorynia, M.; Nowak, J.; Trapczyński, P.; Wolniak, R. Internationalization of Polish Firms via Foreign Direct Investment: A Multiple-Case-Study Approach. In Successes and Challenges of Emerging Economy Multinationals; Marinov, M.A., Marinova, S.T., Eds.; Palgrave Macmillan: London, UK, 2014; pp. 184-216.

56. Hagemejer, J.; Kolasa, M. Internationalisation and Economic Performance of Enterprises: Evidence from Polish Firm-Level Data. World Econ. 2011, 34, 74-100. [CrossRef]

57. Wach, K. Internationalisation and Globalisation as a Wider Context of Europeanisation from Micro and Macroeconomic Perspective. Horyz. Polityki 2014, 5, 11-30. 
58. Domański, B.; Guzik, R.; Gwosdz, K.; Kołoś, A.; Taczanowski, J. European semi-periphery under environmental pressure: The case of urban public bus transportation and private bus-makers in Poland. Int. J. Automot. Technol. Manag. 2016, 16, 301-318. [CrossRef]

59. Covarrubias, V.A.; Ramírez Perez, S.M. Wrapping Up: The New Geographies and Frontiers of the AI have Arrived. Who is Taking the Lead? In New Frontiers of the Automobile Industry. Exploring Geographies, Technology, and Institutional Challenges; Covarrubias, A., Ramirez, S., Eds.; Palgrave Macmillan: Cham, Switzerland, 2020; pp. 455-494.

60. Simon, H. Hidden Champions of the Twenty-First Century: The Success Strategies of Unknown World Market. Leaders; Springer: New York, NY, USA, 2009.

61. Harvey, D. The Enigma of Capital and the Crises of Capitalism; Oxford University Press: Oxford, UK; New York, NY, USA, 2010. 